\title{
Cluster headache: a quasi-rare disorder needing a reappraisal
}

\author{
Paolo Martelletti ${ }^{1}$ and Dimos-Dimitrios Mitsikostas ${ }^{2 *}$
}

Keywords: Cluster headache; Trigeminal autonomic cephalagias; Epidemiology; Burden; Pathophysiology;

Treatment

This Editorial introduces the 2015 Open Thematic Series dedicated to Cluster Headache $(\mathrm{CH})$ and other Rare Headaches. For too long researchers have focused their attention on other most popular, sometimes clumsy or foggy forms of headache, overlooking this important and quasi-rare headache disorder [1].

Apparently $\mathrm{CH}$ represents the most peculiar form among the Trigeminal Autonomic Cephalalgias (TACs). The unbearable periorbital side-locked pain is coupled by ipsilateral cranial autonomic symptoms (conjunctival injection, lacrimation and rhinorrhea) and causes a vast disability although the overall burden of this disease has not yet found a complete systematization.

Especially its chronic form, characterized by more days with attacks than not in the year span, represents a strict minority ( $10 \%$ of $\mathrm{CH}, 0,01 \%$ overall) and hits 70.000 on a sample of 100 millions of people. Even if these numbers are relatively small the impact of this disease is destructive, thus $\mathrm{CH}$ represents a niche worth to be re-focused.

Recently Chronic $\mathrm{CH}(\mathrm{CCH})$ refractory to whichever medical therapy $(\mathrm{rCCH})$ has been systematized from a clinical point of view [2].

The personal burden caused by $\mathrm{CH}$, meant as loss of employment, homebound days and disability is higher in women than in men [3].

$\mathrm{CH}$ lifetime prevalence is $1 / 1000$ and over the past decades a progressive reduction of the male/female ratio has been reported, being now 2.1:1 [4]. Even if $\mathrm{CH}$ is easy to diagnose on the basis of its peculiar features, the timing over the day of the attacks (up to 8), a temporally defined active cluster period (60-90 days) and its seasonal

\footnotetext{
* Correspondence: dimosmitsikostas@me.com

${ }^{2}$ Department of Neurology, Athens Naval Hospital, Athens, Greece Full list of author information is available at the end of the article
}

recurrence, only $1 / 3$ of these patients is rightly diagnosed, with an unacceptable delay of 5.3 years and consequently more than $2 / 3$ of them never receive a correct treatment $[1,5,6]$.

Actually the current pathophysiological theory of $\mathrm{CH}$ is oriented towards a posterior hypothalamic dysfunction [7] but further pharmacological studies shall selectively focus this area. Recently the allele G of the G1246A HCRTR2 polymorphism was been found to be associated with $\mathrm{CH}$, indicating that hypocretin/orexin system's peptides may be involved in the transmission of pain, in autonomic and neuroendocrine functions, and in the pathogenesis of $\mathrm{CH}[8,9]$.

For too many years sumatriptan, verapamil and corticosteroids have been the cornerstones of $\mathrm{CH}$ treatment [1]; we hope that the starting era of monoclonal antibodies against Calcitonin Gene-Related Peptide might include $\mathrm{CH}$ as therapeutic target. An ongoing phase 3 RCT on the use of LY2951742 in episodic CH through its preventative subcutaneous administration every 30 days could change the future management of $\mathrm{CH}$ [10].

Other approaches to chronic cluster headache are the new mini-invasive and non-invasive neuromodulation techniques. The European Headache Federation recommends caution in using these techniques [11] because only few controlled studies have been carried out yet.

Among these new approaches, Vagal Nerve Stimuation (VNS) and sphenopalatine ganglion stimulation (SPG) seem promising but still classified at Class IV evidence [12, 13]; SPG shows contrasting evidence [14]. All these approaches need to be further confirmed and validated by ad hoc RCTs.

Lastly, patients' education is another important topic to be re-considered: sleep pattern changes, alcoholic 
beverages, NO-derived cardiovascular drugs and phosphodiesterase inhibitors widely self-prescribed for erectile dysfunction trigger additional bouts during $\mathrm{CH}$ active phases [1]. Furthermore, a more diffuse physicians education on $\mathrm{CH}$ management should lead to an earlier diagnosis and a more adequate treatment of this headache disorder [15].

Thus we trust that this Open Thematic Series dedicated to Cluster Headache could thicken the attention on a famed and quasi-rare headache disorder.

\section{Author details}

${ }^{1}$ Department of Clinical and Molecular Medicine, Sapienza University, Rome, Italy. ${ }^{2}$ Department of Neurology, Athens Naval Hospital, Athens, Greece.

Received: 15 June 2015 Accepted: 16 June 2015

Published online: 26 June 2015

\section{References}

1. Martelletti P. Pharmacotherapy of cluster headache and beyond. Expert Opinion in Pharmacotherapy 2015; June 1:1-5 [Epub ahead of print] doi:10.1517/14656566.2015.1052741

2. Mitsikostas DD, Edvinsson L, Jensen RH et al (2014) Refractory chronic cluster headache: a consensus statement on clinical definition from the European Headache Federation. J Headache Pain 15:79

3. Rozen TD, Fishman RS (2012) Female Cluster Headache in the United States of America: what are the gender differences? Results from the United States Cluster Headache Survey. J Neurol Sci 317:17-28

4. Manzoni GC (1998) Gender ratio of cluster headache over the years: a possible role of changes in lifestyle. Cephalalgia 18(3):138-42

5. Voiticovschi-losob C, Allena M, De Cillis I et al (2014) Diagnostic and therapeutic errors in cluster headache: a hospital-based study. J Headache Pain 15:56. doi:10.1186/1129-2377-15-56

6. Sánchez Del Rio M, Leira R, Pozo-Rosich P, Laínez JM, Alvarez R, Pascual J (2014) Errors in recognition and management are still frequent in patients with cluster headache. Eur Neurol 72:209-12

7. Goadsby P (2012) Trigeminal autonomic cephalalgias. Continuum (Minneap Minn) 18:883-95

8. Rainero I, Rubino E, Valfrè W, Gallone S, De Martino P, Zampella E, Pinessi L (2007) Association between the G1246A polymorphism of the hypocretin receptor 2 gene and cluster headache: a meta-analysis. J Headache Pain 8:152-6

9. Rainero I, Gallone S, Valfrè W, Ferrero M, Angilella G, Rivoiro C, Rubino E, De Martino P, Savi L, Ferrone M, Pinessi L (2004) A polymorphism of the hypocretin receptor 2 gene is associated with cluster headache. Neurology 63:1286-8

10. ClinicalTrial.gov A study of LY2951742 in participants with episodic cluster headache. Available at: https://clinicaltrial.gov/ct2/show/NCT02397473 [Last accessed 15 June 2015].

11. Martelletti $P$, Jensen $R H$, Antal A, Arcioni R, Brighina F, de Tommaso M, Franzini A, Fontaine D, Heiland M, Jürgens TP, Leone M, Magis D, Paemeleire K, Palmisani S, Paulus W, May A (2013) Neuromodulation of chronic headaches: position statement from the European Headache Federation. J Headache Pain 14:86

12. Nesbitt AD, Marin JC, Tompkins E et al (2015) Initial use of a novel noninvasive vagus nerve stimulator for cluster headache treatment. Neurology 84:1249-53

13. Pietzsch JB, Garner A, Gaul C, May A (2015) Cost-effectiveness of stimulation of the sphenopalatine ganglion (SPG) for the treatment of chronic cluster headache: a model-based analysis based on the pathway $\mathrm{CH}-1$ study. $J$ Headache Pain 16:48

14. Bendersky DC, Hem SM, Yampolsky CG (2015) Unsuccessful pulsed radiofrequency of the sphenopalatine ganglion in patients with chronic cluster headache and subsequent successful thermocoagulation. Pain Pract 15:E40-5

15. Martelletti P, Mitsikostas DD, Lampl C, Katsarava Z, Osipova V, Paemeleire K, Edvinsson L, Siva A, Valade D, Steiner TJ, Jensen RH (2013) Framing education on headache disorders into the Global Burden of Disease Study 2010. The European Headache Federation stands ready. J Headache Pain 14:41

\section{Submit your manuscript to a SpringerOpen ${ }^{\circ}$ journal and benefit from:}

- Convenient online submission

- Rigorous peer review

- Immediate publication on acceptance

- Open access: articles freely available online

- High visibility within the field

- Retaining the copyright to your article

Submit your next manuscript at springeropen.com 